\title{
A CIDADE E SUAS MARGENS: MEMÓRIA E PRÁTICAS DA ÁGUA NA BACIA DO UNA EM BELÉM (PA)
}

\author{
Pedro Paulo de Miranda Araújo Soares (D $ه$
}




\section{RESUMO}

A água exerce papel fundamental na conformação do sítio urbano e da vida social em Belém. Não obstante a presença da água enquanto um elemento capaz de agenciar relações sociais na cidade, a trajetória urbana de Belém é marcada por discursos e políticas públicas responsáveis pela criação de uma antinomia entre água e cidade. A negação da relação com a água, em grande parte, legitima intervenções do Estado nas áreas baixas e úmidas da cidade historicamente ocupadas por migrantes pobres vindos do campo ou de outros estados. O presente artigo é centrado nas práticas cotidianas ligadas aos cursos d'água em Belém, por parte dos habitantes das áreas conhecidas como baixadas, após a conclusão de intervenções nesses espaços, em especial, na região da Bacia do Una. A pesquisa etnográfica que serve de base a este artigo teve como foco as caminhadas pelas marginas de canais da Bacia do Una, na observação participante e no convívio prolongado com moradores dessas áreas, além de entrevistas e conversas informais. As relações desses sujeitos com as paisagens hídricas de seus espaços de pertencimento são alteradas pela urbanização, mas duram no tempo por meio da memória, pois a água também permeia a trajetória dos sujeitos que habitam a cidade e suas margens. Assim, as margens fluviais de Belém devem ser consideradas não apenas como objeto de projetos de urbanização, mas como espaços de sociabilidade em que as práticas cotidianas, informadas pela memória, reconfiguram as políticas implementadas.

Palavras-chave: Memória; Belém; Água; Bacia do Una

\section{THE CITY AND ITS MARGINS: MEMORY AND PRACTICES OF WATER IN THE UNA RIVER BASIN, BELEM (PA)}

\section{ABSTRACT}

Water has a sensitive role in shaping both urban landscape and social life in Belem. In contrast, Belem's urban history is dominated by discourses and public policies responsible for creating an antinomy between city and water. This denial of the relationship with water unfolds, in part, interventions over city lowlands which were historically habitated by poor migrants from the countryside or other states. This article focuses on everyday practices related to water from inhabitants of the areas known as baixadas after the conclusion of a massive urban development program in the Una River Basin. Data was built through ethnographic research specially walks along the river basin channel, participant observation, interviews, and informal conversations with residents from areas affected by the Una River Basin Project. The relationship of these residents with hydric landscapes is altered by urbanization, but last in time through memory, since water articulates with their collective and individual trajectories. Thus, Belem's river margins must be considered not only as objects of intervention, but also as spaces of sociability in which everyday practices informed by memory reshape the public policies on water.

Keywords: Memory; Belem; Water; Una River Basin.

\section{LA CIUDAD Y SUS MÁRGENES: MEMÓRIA Y PRÁCTICAS DEL AGUA EN LA CUENCA DEL UNA EN BELÉM (PA)}

\section{RESUMEN}

El agua ejerce un papel fundamental en la conformación del sitio urbano y de la vida social en Belén. No obstante, la presencia del agua como un elemento capaz de agenciar relaciones sociales en la ciudad, la trayectoria urbana de Belém es marcada por discursos y políticas públicas responsables por la creación de una antinomia entre agua y ciudad. La negación de la relación con el agua, en gran parte, legítima intervenciones del Estado en las áreas bajas y húmedas de la ciudad históricamente ocupadas por migrantes pobres que llegan del campo o de otros estados. El presente artículo se centra en las prácticas cotidianas conectadas a los cursos de agua en Belém, por parte de los habitantes de las áreas conocidas como bajas, después de la conclusión de intervenciones en esos espacios, en especial, en la región de la Cuenca del Una. La pesquisa etnográfica que sirve de base a este artículo tuvo como enfoque las caminatas por las márgenes de los canales de la Cuenca del Una, en la observación participante y en el convivio prolongado con residentes de esas áreas, más allá de entrevistas y conversaciones informales. Las relaciones de esos sujetos con los paisajes hídricos de sus espacios de pertenencia son alteradas por la urbanización, pero perduran en el tiempo por medio de la memoria, pues el agua también permea la trayectoria de los sujetos que habitan la ciudad y sus márgenes. Así, las márgenes fluviales de Belém deben ser consideradas no sólo como objeto de proyectos de urbanización, sino como espacios de sociabilidad en que las prácticas cotidianas, informadas por la memoria, reconfiguran las políticas implementadas.

Palabras clave: Memória, Belén; Agua; Cuenca del Una 


\section{INTRODUÇÃO}

Em "A água e os sonhos", Bachelard (2013) garante que nenhum outro elemento natural tem tanta capacidade de evocar devaneios quanto a água. Para o autor, o mar revolto poderia encontrar ressonâncias nos estados psíquicos mais coléricos. Entregar-se às imagens de grandes massas d'água como um rio-mar ou uma baía, por sua vez, pode evocar a ideia de coesão e a harmonia. Já as virtudes da água corrente evocam o movimento, o devir das coisas, o dinamismo constante da vida e do fluxo de ideias na psique individual.

Moreira (1989), em um compêndio de trabalhos denominado Geografias Mágicas, segue esta mesma direção ao tratar da simbologia dos pântanos. Porém, antes de tratar propriamente deles, o autor define os rios como cursos d'água que "inspiram movimento e ação, e a forma por excelência disso é o espírito de aventura" (Moreira 1989:44) motivado pelos rios. Os lagos, por sua vez, para este autor "sugerem quietação e placidez, estados mentais propícios ao recolhimento e ao devaneio" (Moreira 1989:44). De todo modo, Bachelard (2013) e Moreira (1989) concordam que a imaginação está repleta de imagens da água que remetem à cognição e à vida interior, assim como às práticas daqueles que se concebem como sujeitos no mundo.

Em Belém ${ }^{1}$, a água desempenha um papel que vai além de ser um recurso, sendo também fundamental para a vida social como um agente que se insere nas mediações do cotidiano. Essa cidade é uma ponta de terra rodeada por águas doces. A Leste, a cidade é banhada pela Baía do Guajará, que dá acesso por barco até a Ilha de Marajó. A Oeste, a cidade é costeada pelo rio Guamá, também navegável e que conduz à região Noroeste do estado. Essas duas grandes massas de água doce que emolduram a cidade possuem inúmeros afluentes e ramificações que hoje a recortam na forma de paisagens fluviais agonizantes, isto é, canais pavimentados, valões e esgotos a céu aberto.

Esses cursos d'água percorrem, em sua maioria, bairros populares que foram ocupados no decorrer do século XX por migrantes vindos do interior do Pará ou de outros estados. Muitos dos canais que passam por esses bairros foram no passado rios, igarapés e córregos. Outros canais foram abertos posteriormente - tanto no século XIX quanto no século XX - em virtude de obras de saneamento que visavam à drenagem de áreas pantanosas e

1 A cidade conta com uma população de 1.499 .641 pessoas, estimada pelo IBGE para 2020 . 
constantemente alagadas no interior da cidade conhecidas como baixadas² (Feitosa 1994). Grande parte desses cursos d'água também foi aterrada ou transformada em galerias de esgoto pluvial desaparecidas sob a pavimentação das ruas da urbe (Feitosa 1994).

Dentre essas áreas de Belém que são úmidas e baixas, observando-se a presença e rios e córregos, está a Bacia do Una, que compõe uma área de 36,64 $\mathrm{km}^{2}$ com 397.339 habitantes ${ }^{3}$, sendo que $19 \%$ do território da bacia são compostos por áreas alagáveis (Silva 2003). Devido à grande extensão territorial dessa bacia, esta pesquisa etnográfica se desenvolve em alguns pontos dela, próximos aos canais e cursos d'água que a recortam, a exemplo do Canal do Galo.

Embora a Bacia do Una tenha sofrido intervenções do poder público desde meados da década de 1990, com o Projeto de Macrodrenagem da Bacia do Una, uma significativa parte de sua população continua vivendo em condições de precariedade habitacional, devido aos agravos ambientais provocados pela povoação das margens dos antigos rios, canais e igarapés da cidade, bem como em função das políticas públicas implementadas nessas áreas. Como um reflexo do quadro maior das políticas públicas de saneamento que tiveram lugar em Belém até o fim do século XX e início do século XIX, o destino dos veios d'água da Bacia do Una também foi o aterramento, a transposição de seus cursos para canais retificados para drenagem de uma determinada área, assim como a sua transformação em esgotos a céu aberto.

Em outros trabalhos concentrei-me bastante da dimensão da memória presente nas narrativas dos sujeitos que vivem as transformações no espaço urbano de Belém, com foco nas suas trajetórias de vida ligadas à relação com a água (Soares 2016, Soares e Hazeu 2019), bem como na Ecologia Política das inundações urbanas em Belém (Soares e Cruz 2019, Soares et al. 2020). Neste trabalho, dou mais destaque às práticas e modos de conhecimento dos moradores de uma área da Bacia do Una envolvendo as paisagens hídricas em transformação em seu cotidiano. As práticas, enquanto modos de saber-fazer não sabidos dificilmente expressos em palavras (Chevalier 1991), estão ligadas a modos de viver e suas transformações. Por essa razão, também evocam a memória e pela memória se expressam.

Para o presente artigo, é necessário assinalar como o fenômeno da memória é tratado pela

2 "As baixadas existentes em Belém são áreas inundadas ou sujeitas às inundações - decorrentes, em especial, dos efeitos das marés - e ficaram conhecidas, principalmente a partir da década de 60 , por serem espaços de moradia das camadas sociais de baixo poder aquisitivo" (Trindade Jr. 1997: 64).

3 Os bairros que hoje compõem esta bacia hidrográfica são 16 integrais: Pedreira, Telégrafo, Barreiro, Sacramenta, Miramar, Maracangalha, Fátima, Souza, Castanheira, Marambaia, Val-de-Cans, Mangueirão, Benguí, Parque Verde e Cabanagem. Quatro bairros a compõem parcialmente: Umarizal, Nazaré, São Brás e Marco. 
perspectiva que considera relevante a compreensão do mundo urbano por uma Etnografia da Duração. Para além da simples lembrança do passado, a memória é entendida como a reconstrução do passado como experiência de vida a partir de questões que são relevantes no presente para os sujeitos. Conforme Eckert e Rocha (2005:154): "a etnografia da duração, nesse sentido, vislumbra o tratamento da memória como conhecimento de si e do mundo, a partir do trabalho de recordar narrado pelos sujeitos”. Desse modo, para as reflexões propostas neste artigo, parto do princípio de que as práticas e experiências de habitantes da Bacia do Una com o ambiente hídrico e com o saneamento estão consubstanciadas às suas trajetórias de vida e constituem uma expressão do ponto de vista dessas pessoas sobre a experiência temporal de Belém.

Sobre a compreensão da cidade - e de sua relação com o elemento água - enquanto um objeto temporal (Eckert \& Rocha 2005), isso significaria dizer que as experiências de seus habitantes estão situadas em um movimento de mudanças e transformações constantes da urbe que se efetuam com o passar do tempo. Trata-se de entender como os sujeitos acomodam e subjetivam o tempo da cidade em relação às suas trajetórias individuais e coletivas, ou seja, como os habitantes belenenses incorporam as experiências vividas nos ritmos temporais na cidade às suas temporalidades interiores, consolidando esses tempos diversos em uma duração.

No plano metodológico, esta forma de produzir conhecimento em Antropologia sobre a cidade confere relevância aos modos de vida e saberes informais dos seus habitantes. Assim, é necessário observar como a realidade urbana é construída, negociada e vivenciada no cotidiano, mostrando-se ao olhar, à audição, ao tato e ao olfato do etnógrafo por meio dos gestos, dramas sociais e formas de sociabilidade dos personagens urbanos (Eckert 2010). Este trabalho, portanto, está focado em duas situações ligadas às práticas com o ambiente hídrico: as experiências e apropriações das margens dos canais de macrodrenagem que compõem a Bacia do Una e o banho nesses canais e na Baía do Guajará praticado pelos habitantes das áreas próximas a esses cursos d'água. Sobre a proximidade com esses corpos hídricos, é necessário destacar que são espaços considerados bastante poluídos, na medida em que recebem não apenas as águas servidas das residências de seu entorno, mas também o esgotamento sanitário da cidade. Logo, suas práticas também recriam e reconfiguram esses espaços cuja identidade contextual oscila entre o esgoto e o igarapé ou rio.

Sobre a inclusão da Baía do Guajará no universo da Bacia do Una, os loci da pesquisa são considerados a partir da perspectiva sistêmica de 
Bateson (1987), que admite não apenas a unidade analítica entre os corpos d'água que correm no interior da cidade e a grande massa hídrica ao redor da cidade, mas também a unidade na percepção dos interlocutores sobre esse sistema, na medida em que o deslocamento dos canais para a orla fluvial faz parte de sua experiência cotidiana.

Neste trabalho, a ideia de margem é tomada em sentido literal quanto às proximidades dos canais e da baía, mas também em referência ao sentido empregado por Das e Poole (2004) a respeito das margens do Estado. Nesse último caso, e para os fins deste artigo, as margens são tratadas como espaços de indeterminação entre o formal e o informal urbanos. Essa característica de liminaridade é percebida quando locais ocupados informalmente por populações de baixa renda são beneficiados por projetos de infraestrutura urbana e incorporados à "cidade formal", porém, logo em seguida abandonados novamente. Isso resulta em arranjos de urbanização parcial em que as obras realizadas - sem manutenção, sem alcançar a funcionalidade prevista ou sem dialogar com as necessidades do público-alvo não necessariamente implicam na melhoria das condições de vida dos sujeitos.

Essa liminaridade também se traduz pelas dinâmicas entre presença e ausência do Estado, ora presente por meio do policiamento ostensivo, ora ausente pela falta de coleta de lixo e de manutenção dos sistemas de drenagem e de esgotamento, por exemplo. Entretanto, as margens, justamente por serem esses espaços de múltiplas indeterminações, tornam possíveis as criatividades, as negociações e as resistências daqueles que as habitam. Estar à margem não deve significar apenas a exclusão dos sujeitos em relação a um ideal de cidadania urbana almejado pelas políticas públicas implementadas. Antes disso, a condição de margem implica que o projeto de domínio da cidade sobre a água, e as subjetividades ligadas à água, está incompleto e aberto ao agenciamento dos sujeitos sobre o meio em que vivem e sobre si próprios.

Este artigo está organizado da seguinte maneira: primeiro, são examinados alguns discursos sobre a relação entre cidade e água e seus desdobramentos na forma de políticas cujo resultado foi apartar a urbe de suas águas, além de marginalizar aqueles que continuaram a viver nas áreas úmidas da cidade. Em seguida, é apresentado material etnográfico sobre as práticas e experiências de moradores com as águas urbanas em uma área beneficiada pelo Projeto Bacia do Una e em uma parte da orla da Baía do Guarajá, conhecida como Vila da Barca. O tópico subsequente apresenta uma reflexão sobre as experiências e práticas dos moradores com a água no contexto urbano de Belém, seguido pelas considerações finais. 


\section{PROJETO(S) PROMETEICO(S)}

Quatro pétalas se estendendo do eixo da matriz pelas terras pardas dos barrancos, dilatando, expandindo seus próprios rumos, vencendo baixadas, matas e pirizais, transformando os fundamentos do presépio no mais opulento centro de cultura e progresso da Amazônia Brasileira (Meira Filho 1973: 44).

O trecho acima, pertencente ao literato paraense Augusto Meira Filho, corporifica a construção da antinomia entre água e cidade em Belém. Publicada em uma coletânea de ensaios no ano de 1973, essa crônica discorre sobre a cidade de Belém setecentista, que começava a se expandir para além do seu primeiro núcleo colonial. A vocação de "opulência" e "progresso" só seria realizada "vencendo baixadas, matas e pirizais", ou seja, conquistando a cidade de suas águas. A água, nesse caso, caracteriza os espaços de fronteira e de expansão urbana.

O trabalho de Cardoso e Ventura Neto (2013) discute como na trajetória urbana de Belém, cidade e natureza, em grande parte representada pela água, foram historicamente tratadas como categorias opostas. Para os autores, os rios serviram como o primeiro vetor de expansão urbana na Amazônia, constituindo um sistema social ribeirinho no qual a água conduzia o transporte e o comércio, além de aglutinar as moradias. No entanto, tão logo cidades como Belém e Manaus tiveram oportunidade de realizar melhorias em sua infraestrutura urbana, o modelo de urbanização escolhido implicou uma determinada (est)ética em relação às águas que percorriam o interior da cidades. Entretanto, a adoção de um modelo de urbanização e de políticas públicas relativas aos rios urbanos não se deu sem dilemas, como demonstram Valle e Oliveira (2003) sobre a Manaus do século XIX:

Os caminhos dos igarapés eram também os caminhos das novas ruas. O desafio da engenharia européia contra a natureza, diante da decisão da escolha de um modelo de urbanização: construir Veneza ou Paris nos trópicos? Decide-se traçar linhas retas, aplainarse, superar obstáculos. Trazer para a floresta os boulevards parisienses era o maior desafio. (Valle \& Oliveira 2003: 158).

O trecho acima mostra como, já no século XIX, estavam lançadas as bases e referências socioculturais das intervenções urbanísticas em igarapés, rios e áreas alagadiças no interior das cidades. Não apenas Belém e Manaus, mas grande parte das capitais brasileiras adotou o paradigma parisiense ao longo do século XX, o qual se baseava em operações agressivas de ensecamento e canalização de cursos d'água ${ }^{4}$. No entanto, isso não ocorreu sem que houvesse resistência. O modelo veneziano, pouco explorado, propunha uma ética diferenciada em relação aos

4 Sobre o tema, destacam-se os trabalhos de Sant'anna (2007) sobre São Paulo (SP) e de Devos et al. (2010) a respeito de Porto Alegre (RS). 
cursos d'água urbanos. Tal como em Veneza, os riachos e igarapés poderiam ser utilizados a favor da cidade enquanto vias de circulação interna, mas também como fonte de beleza e personalidade urbana. Em 1909, o governador do Amazonas, Coronel Antônio Clemente Ribeiro Bittencourt, lamentava o aterramento dos igarapés no centro de Manaus. Dizia ele que os igarapés, se mantidos com seu leito original, tornariam "Manaus não só a linda princesa do Rio Negro, mas ainda uma Veneza poética, mais gentil e menos sombria, enfeitada pela luminosa vegetação amazonense" (Valle \& Oliveira 2003:174).

Belém, drenada por igarapés e seus afluentes, também foi o cenário de devaneios venezianos. Ao longo de sua história houve projetos que buscaram resistir às narrativas progressistas hegemônicas de domínio irrestrito sobre a água. Um exemplo é o que propôs o Major Engenheiro Gaspar João Gronfelts em 1771. Em seu "Estudo de Geografia Urbana”, Antônio Rocha Penteado (1968) escreve que Gronfelts pretendia utilizar o grande alagado do Piry - ora descrito como igarapé, ora como um pântano - para criar um sistema de canais que interligassem diferentes pontos da cidade pela água (Penteado 1968). O material levantado por Almeida (2011) também mostra que Gronfelts planejava dragar o leito do Piry, aprofundando-o para torná-lo navegável durante o ano inteiro.
A cidade então teria duas entradas fluviais, uma pelo local onde hoje é a enseada de desembarque no Ver-o-Peso e a outra onde existia um igarapé que posteriormente se transformou no Canal do Reduto (Figura 1).

O projeto de Gronfelts encontrou entusiastas. Um deles foi o historiador e geógrafo português radicado no Pará, Antônio Ladislau Monteiro Baena, que em seu "Ensaio Corográfico da Província do Pará”, de 1839, escreveu:

Em vez de empregar trabalhos
hidráulicos para obter a excisão desta
lezira era melhor ir com a indicação
da natureza e aperfeiçoar sua obra,
fazendo um lagamar que as águas da
inundação do rio e as ascendentes no
fluxo do mar naturalmente ocupassem
[...] a Cidade de Belém do Pará ficará
sendo mais bela que a Adriática Veneza
tão celebrada. (Baena 1839 apud
Penteado 1968:113-4).

A referência ao modelo de Veneza é também presente nas palavras de Baena (1839). Ainda assim, essas obras, que nunca foram executadas, aparecem como devaneios sobre uma cidade que Belém poderia ter sido, representando o renascimento mítico da afinidade com as águas que ela perdeu ao longo de sua urbanização. O apoio de Antônio Baena à ideia de Gronfelts foi, no entanto, tardio. Em 1803, as obras de aterramento do Piry já haviam começado, obliterando o projeto do engenheiro.

Ao contrário do que vislumbraram Gronfelts e Baena, o que se observou nos séculos seguintes 
foram tentativas de suprimir o elemento água do interior da cidade, além da marginalização das áreas que permaneceram úmidas e de seus habitantes. As ideologias de disciplina da água passariam por diversos renascimentos ao longo da história de Belém, permanecendo no repertório de técnicos e gestores até os dias de hoje. Esse processo de redundância de ideias estaria, porém, sempre calcado no mito prometeico do progresso e do triunfo da racionalidade técnica aplicada a uma natureza vista como caótica e imprevisível (Kaika 2005).
Ao tratarem sobre a Belém contemporânea, Cardoso e Ventura Neto (2013) discutem a ideia da presença de rios e várzeas como obstáculo à expansão da cidade, sobretudo no que diz respeito à incorporação de novas áreas ao mercado imobiliário. Assim, a concepção da natureza como algo incontrolável e incompatível com a cidade - do ponto de vista do capital imobiliário e do Estado justifica a realização de intervenções urbanísticas que necessitam de grandes investimentos de capital e de trabalho. Na Bacia do Una, a primeira intervenção do tipo macrodrenagem foi executada

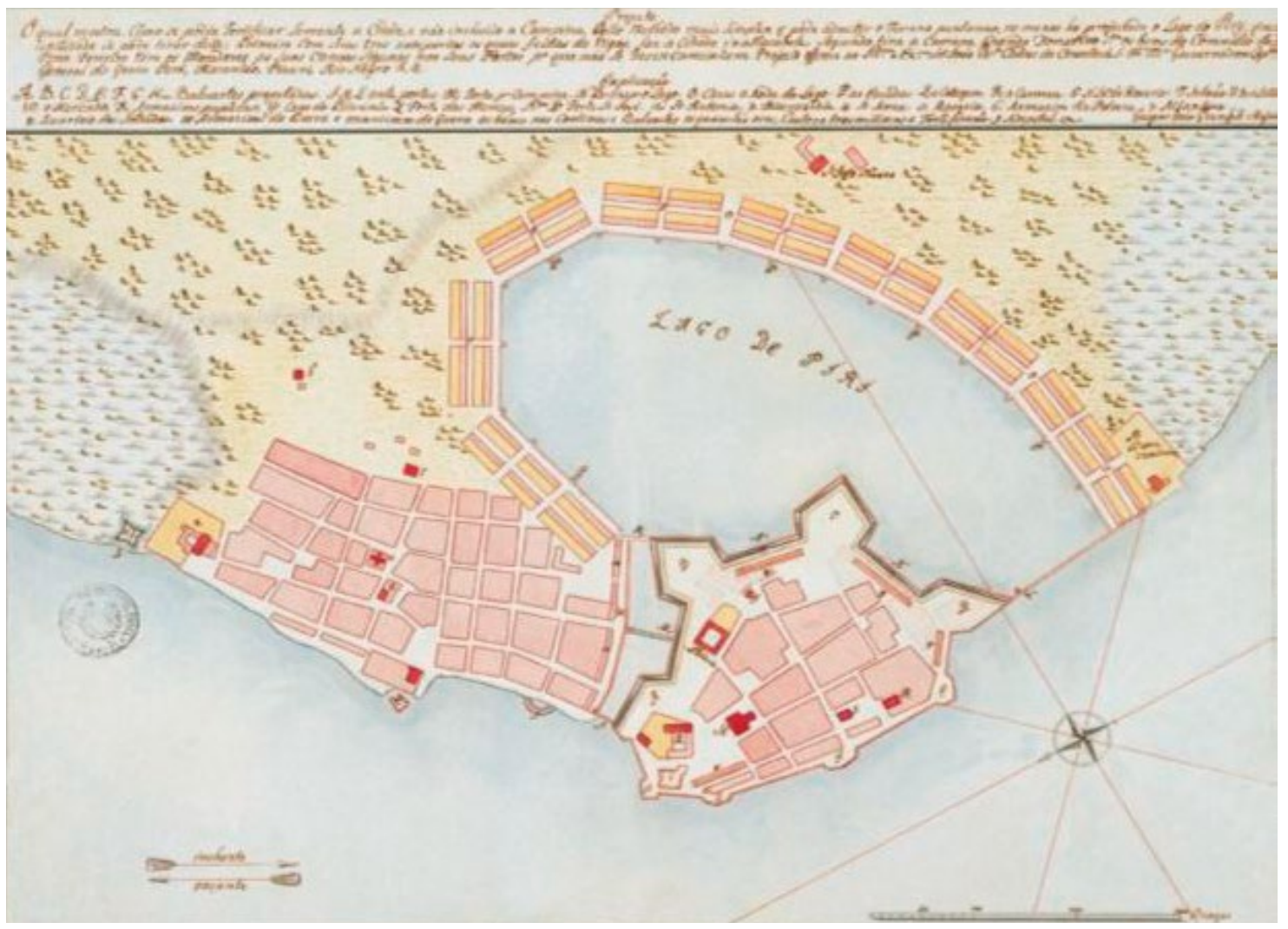

Figura 1 - O projeto de Gronfelts. Fonte: Almeida (2011). 
no final da década de 1970, quando uma parte do igarapé São Joaquim foi canalizada e famílias que moravam sobre a água foram reassentadas em um conjunto habitacional ${ }^{5}$ (Abelém 1988). Essa experiência no canal São Joaquim foi considerada como um programa-piloto para as intervenções subsequentes, como foi o caso do Projeto de Drenagem, Vias, Esgoto e Água das Zonas Baixas de Belém, também chamado de Projeto Una, Projeto de Macrodrenagem da Bacia do Una ou PMU, que seria executado entre 1993 e 2004.

Os documentos da época davam destaque à magnitude das obras do PMU, como aparece abaixo em um relatório da Cosanpa (Companhia de Saneamento do Pará), que caracterizada o projeto antes de sua execução:

O Projeto foi concebido com o objetivo de marcar o início de uma grande transformação a ser procedida nas Baixadas do Una, com reflexos na Cidade de Belém como um todo. Assim sendo, serão implementadas através dos Projetos, obras de retificação dos igarapés e revestimento de suas margens; obras de microdrenagem com a execução de sarjetas, caixas captadoras de águas pluviais, redes coletoras e demais dispositivos; obras de implantação de sistema viário compatível e equipamentos comunitários importantes e necessários, além de outras.

Complementarmente será realizado um amplo programa de educação comunitária, sanitária e ambiental, no sentido de dotar as populações de conhecimento e instrumentos capazes de manter os benefícios conquistados, preservando o meio ambiente e assegurando a conquista de uma melhoria de suas condições de vida, meta tão ansiosamente desejada. (Feitosa 1994: 247).

Um relatório do Governo do Estado, publicado em 2006, contabilizou que o projeto trabalhara em 24,9 $\mathrm{km}$ de canais de macrodrenagem e construiu 1,8 km de galerias subterrâneas (Pará 2006). A macrodrenagem da Bacia do Una ainda foi completada pela instalação de comportas na foz dos canais do Una e do Jacaré, de modo a evitar a livre entrada das águas da Baía do Guajará no interior da cidade e, assim, evitar inundações (Pará 2006). Dentre as medidas relacionadas ao esgotamento sanitário, o relatório indica que foram instaladas 25.731 fossas sépticas individuais e 91 fossas coletivas nas áreas beneficiadas. No entanto, o próprio projeto conectava essas fossas ao sistema de macrodrenagem recém-construído. A partir de então, antigos igarapés se tornaram canais de drenagem, seus fluxos em direção à Baía do Guajará foram bloqueados e uma bacia hidrográfica foi transformada em um sistema técnico para o acúmulo de águas pluviais e de esgotamento sanitário, cujo destino é a Baía do Guajará.

5 Certamente não foi a primeira obra de macrodrenagem ocorrida na capital. Desde a década de 1960, o antigo DNOS (Departamento Nacional de Obras e Saneamento) já executava obras pontuais de canalização de cursos d'água em Belém, com destaque para o Canal da Avenida Tamandaré (entre 1962 e 1967), o resquício de um antigo pântano denominado Piry, e para a Avenida Visconde de Souza Franco (entre 1968 e 1973), onde antes existia o Igarapé das Armas (Trindade Jr. 1997). 
Até os dias de hoje, o PMU ainda representa a tentativa mais ambiciosa de intervenção urbanística nas baixadas de Belém para resolver problemas habitacionais e de saneamento, tanto pela sua extensão territorial, quanto pelo escopo de suas obras. O Projeto Una também foi a primeira experiência de macrodrenagem executada sobre o território de uma bacia hidrográfica (36,64 ha) e também a primeira grande obra realizada em Belém com financiamento de uma instituição financeira multilateral, o BID (Banco Interamericano de Desenvolvimento). O total de investimentos no projeto foi de US\$ 312.437.727 (Pará 2006).

Mesmo com todo esse investimento, no inverno de 2005 -- o primeiro após declarada a conclusão do projeto - uma grande chuva caiu sobre a cidade e o recém-inaugurado sistema de macrodrenagem não foi capaz de armazenar aquela quantidade de água, o que resultou em inundações em diversos pontos da Bacia do Una. Com as inundações, também ficam comprometidos outros sistemas instalados pelo PMU, como o de esgotamento sanitário e o de abastecimento de água. Alagamentos e inundações por transbordamento de canais de macrodrenagem continuaram a se repetir nos anos subsequentes e até os dias de hoje.

\section{PRÁTICAS DA ÁGUA}

Intervenções como o Projeto Una sobre os sujeitos de um território são geralmente marcadas por relações de poder e por desigualdades de classe. Trata-se, antes de tudo de intervenções sobre áreas historicamente ocupadas por migrantes pobres do interior ou de outros estados que se estabeleceram nos terrenos baixos e úmidos da cidade, nas encostas dos igarapés e sobre o seu leito, em locais sujeitos a inundações pela ação das chuvas e das marés. Esse padrão de ocupação nas chamadas baixadas está ligado, por um lado a estratégias de sobrevivência que buscam assegurar a proximidade do trabalho ao local de moradia e as dificuldades de acesso ao mercado formal de terras (Trindade Jr. 1997). Por outro, a escolha desses lugares para moradia também está condicionada às redes de relações de familiares e amigos que dão suporte aos migrantes que chegam em Belém (Soares \& Haze, 2019).

A lógica da ocupação desses espaços obedece às necessidades e relações estabelecidas entre seus habitantes que, por conta própria, e a partir das estratégias de trabalho coletivo conhecidas como mutirão, constroem um sofisticado sistema de casas e ruas em estivas sobre a água, por onde se deslocam internamente e em direção às áreas mais altas. Com o tempo, alguns desses lugares chegam a ser aterrados, também a partir do trabalho coletivo de seus moradores. Portanto, não se tratam de ocupações "desordenadas", como 
classificam alguns especialistas. Ao contrário, possuem uma ordem que lhe é interna e desafiam as lógicas de organização espacial burguesas e industriais (Lefebvre 2004) baseadas em um ideal de racionalidade e linearidade.

Projetos como a macrodrenagem da Bacia do Una tem o objetivo não apenas de intervir sobre o meio físico, mas também sobre os habitantes desses territórios e seus modos de vida, implicando um nível de controle que evoca as ideias de Foucault (2002) sobre biopolítica. Ainda que estejam baseados na identificação e solução de problemas habitacionais e de saneamento, como a instalação de uma série equipamentos e serviços antes inexistentes nesses locais e reorganizando o espaço e as relações sociais.

Essa reorganização executada pelo Estado integra as áreas irregulares à malha urbana facilitando a administração da cidade como um todo e também cria um quadro sinóptico através do qual a máquina administrativa pode melhor localizar e controlar os cidadãos. Isso se reflete na regularização de serviços urbanos de luz e/ou água prestados por empresas estatais ou privadas. O espaço também se torna mais legível e acessível para as ações de aparelhos de Estado, como a Polícia, por exemplo.

Outros autores identificaram o Projeto Una como um projeto cuja essência esteve ligada à criação de infraestrutura viária responsável pela comunicação entre quadras e bairros antes relativamente isolados (Pereira 2003). A criação da infraestrutura viária, por sua vez, cria vetores de expansão do mercado imobiliário, sempre em busca da apropriação de novas áreas (Trindade Jr. 1997).

Com relação às paisagens hídricas urbanas, o Projeto Una foi responsável por institucionalizar as relações entre cidade e natureza nas margens dos canais de macrodrenagem. Por exemplo, a presença de muretas - ou guarda-corpos - separando as pistas marginais dos taludes dos canais e a ausência de estruturas para acesso à água na forma de pequenos portos ou trapiches expressam que o sistema de macrodrenagem é um espaço interditado aos moradores do local e sem nenhuma utilidade além do acúmulo e escoamento do esgoto pluvial e também do esgotamento sanitário. Assim, essas intervenções também objetivam disciplinar os habitantes desses territórios sobre os usos da água e dos equipamentos implementados, devendo gerar certa previsibilidade sobre as práticas dos habitantes das áreas beneficiadas em relação à política pública.

No entanto, apesar das mudanças experimentadas em seus espaços de pertencimento, na vida cotidiana os sujeitos continuam a conviver nas proximidades dos cursos d'água e procuram 
interpretar e criar sentidos sobre as transformações advindas com a urbanização, mesmo com o colapso dos sistemas implementados pelo Projeto Una, o que fica evidente com os frequentes alagamentos e inundações por transbordamento dos canais de macrodrenagem. Na vida cotidiana, as práticas reconfiguram os significados produzidos pela política pública e, ancoradas na memória ambiental das águas urbanas em Belém, reimaginam a relação entre cidade e suas águas. É isso que mostram os exemplos etnográficos a seguir sobre as práticas relativas aos canais que recortam a cidade e à orla fluvial de Belém.

\section{Inverno na Mena Barreto}

A Mena Barreto corresponde a uma área no interior de um quarteirão no bairro do Telégrafo, mais precisamente no perímetro que compreende a rua Curuçá, a travessa Djalma Dutra, a travessa Coronel Luís Bentes e o Canal do Galo. Trata-se de um local que foi beneficiado pelas obras do Projeto de Macrodrenagem da Bacia do Una. Ou seja, onde antes havia uma comunidade de casas palafitas e pontes cercadas por igarapés, hoje existem casas de alvenaria, vias pavimentadas com blocos hexagonais e sistemas de esgotamento sanitário e pluvial cujo destino das águas é o Canal do Galo. Os moradores do local chamam-no de "ilha", pois a configuração do local o isola do restante do quarteirão. De fato, embora as suas entradas pela Djalma Dutra, pela Coronel Luís Bentes e pela marginal esquerda do Canal do Galo recebam o nome de passagem Mena Barreto, no interior da quadra, a passagem se ramifica em diversas vielas e becos. A Mena Barreto, portanto, pode ser definida como um território que se formou há muito tempo em função da presença de um curso d'água ou de seu baixo nível topográfico em relação ao restante do bairro e que conservou parte de sua configuração espacial até os dias de hoje apesar dos aterramentos realizados pelos moradores e das intervenções urbanísticas por parte do Estado.

Estabeleci moradia durante seis meses na comunidade $^{6}$ como parte das estratégias do trabalho etnográfico. Aluguei um kitnet (quarto com cozinha e banheiro) no local, com o objetivo de estar mais próximo do campo de pesquisa, de criar mais oportunidades para conhecer lugares e interlocutores, de observar a vida na comunidade e as relações estabelecidas com as águas urbanas.

A experiência de morar no campo de pesquisa visava criar condições para a produção conjunta de dados etnográficos e experimentar as dinâmicas

6 A chegada à Mena Barreto se deu por intermédio de uma familiar idosa que realizava trabalhos sociais e religiosos na comunidade. Essa familiar apresentou suas amigas de mesma faixa etária durante uma missa de $7^{\circ}$ dia que ocorreu no local. 
antropológicas entre um "estar lá" e um "estar aqui” (Geertz 1991), mesmo que em minha própria cidade, além de provocar o estranhamento do familiar (Velho 1994) necessário à pesquisa etnográfica. "Estar lá” permitiu caminhar pelas margens do Canal do Galo até afeira do Barreiro, perceber as atitudes dos moradores durante as chuvas, observar o nível da lâmina d'água do Canal do Galo se elevar em direção ao transbordamento, além de tomar um banho na maré da Baía do Guarajá acompanhado dos moradores da Mena Barreto, experiências que serão abordadas a seguir.

Quando chovia na Mena Barreto, a primeira coisa que se ouvia era o barulho das crianças correndo na chuva. Eu ouvia seus gritos de euforia, seus passos rápidos debaixo da minha janela e quando olhava para fora do kitnet, elas estavam chutando a água empoçada e tomando banho nas biqueiras que caem do telhado das casas. A chuva para as crianças é motivo de alegria e brincadeira. Essas crianças, se tiverem entre 8 e 12 anos, provavelmente cresceram no cenário que hoje é encontrado na Mena Barreto: as ruas aterradas e pavimentadas com espaço para correr e brincar, com meio-fio por onde escorre a água da chuva e alguns poucos pontos mais baixos onde a água se acumula formando pequenas "lagoas". É por aí que as crianças passam correndo e levantando a água com seus pés. Quando a rua se torna mais larga, é possível inclusive jogar futebol sobre o chão composto por blocos de concreto. Se com um chute mais forte a bola cai dentro do canal, paciência: alguém tem que entrar ali para pegá-la de volta, pois o jogo precisa continuar. A sociabilidade das crianças na chuva evoca os aspectos lúdicos do contato com a água (Figura 2).

Muito diferentes são as atitudes dos adultos mais velhos nas ocasiões em que a chuva cai um pouco mais intensa do que o costumeiro. Enquanto as crianças corriam pela rua, minha vizinha Dona Júlia (63 anos na época) permanecia em sua janela com um olhar preocupado. Inquieta, olhava para o céu examinando a intensidade da chuva que caía e examinava a vazão e o volume da água que corria pelo meio-fio em frente à sua casa. Percebendo que Dona Júlia estava preocupada com os efeitos da chuva, dirigi-me a ela da minha janela, perguntando-lhe se já tinha visto o canal transbordar. Ela disse que sim. Disse também que no passado a rua ficava inundada e a água chegava até o local onde estávamos. "Tomara que hoje não encha”, concluiu.

Pouco tempo depois tive a oportunidade de entrevistar Dona Júlia na sala de sua casa. Dona Júlia e seu irmão Ico são filhos da falecida Dona Nenê, uma importante líder comunitária e principal responsável pela fundação da Comunidade Eclesial de Base ainda hoje existente na Mena Barreto. 
Durante a entrevista, Dona Júlia trouxe à tona parte da experiência relacionada às chuvas $\mathrm{e}$ inundações na área:

Aqui enchia, quando era essa época agora de março, abril, aqui enchia tudo. A água batia aqui [apontou para a parede uma altura que se aproximava de meio metro do chão]. Demorava três dias pra secar, a gente ficava esperando, eu, os meninos, a gente ficava tudo lá pra cima [no segundo pavimento da casa]. E com a água naquela altura, como é que a gente fazia pra comprar um pão, né? A gente esperava alguém passar e pedia. A pessoa trazia pela água mesmo. Mas era perigoso. Porque não dava pra saber onde era ponte $\mathrm{e}$ onde era água. Aí criança caía na água, velho caía.

Aqui era tudo ponte. Desde lá da Djalma. Aí depois aterraram até aí a entrada, mas aqui continuou ponte. A ponte passava aqui na frente. Aqui era uma vila de casas, não tinha tanta casa. Aí na frente onde é teu kitnet era um comércio, uma mercearia boa do pai da dona [dos kitnets]. O igarapé passava bem debaixo. Aí depois que passou por aqui a macrodrenagem, né? Que abriram o canal e aterraram o igarapé. Isso foi muito bom pra gente, porque aqui era muito ruim. As casas não tinham esgoto, tudo do sanitário caía direto na água, né? Agora pensa no que acontecia quando enchia e a aquela água vinha toda pra cima...

A reação de Dona Júlia diante da chuva de domingo que eu também acompanhava da janela de casa mostrou as diferenças geracionais da relação com a chuva. Os habitantes mais antigos da Mena Barreto são pessoas marcadas pelas consequências das chuvas fortes de inverno do passado. Para eles, a temporalidade do lugar é marcada por um antes e um depois da urbanização, pelo tempo das pontes que se contrapõe ao tempo do asfalto. Já nascidas no asfalto, as crianças associam a chuva a motivo de festa.

Mesmo após a Macrodrenagem do Una, antigos moradores como Dona Júlia guardam lembranças da subida do nível das águas, mantendo-se em um estado de constante alerta. Outro fator também contribui para a vigília de Dona Júlia em relação à chuva: vários moradores com quem conversei afirmaram que houve transbordamento do Canal do Galo em função da chuva nos anos anteriores, ou seja, posteriormente à conclusão das obras de drenagem na área. Um desses moradores foi Seu Laércio, um senhor de 73 anos na época da pesquisa, que migrou para a Mena Barreto quando ainda era adolescente, vindo de uma localidade no interior do arquipélago do Marajó (PA) chamada Boa Vista. Sobre as chuvas na Mena Barreto, ele contou:

Aqui já aconteceu umas três vezes, tem mancha pela parede aí. Da água entrar aqui e dava no meio da minha perna assim. Então essa água ela vai desembocar lá no Una. Tem o Una e tem o Jacaré. Tem duas comportas. Tem a do Una que é mais antiga e tem outra mais lá na frente. Eles abrem lá quando a maré tá vazando que é pra água ir embora tudinho. Porque se chover e não tiver escoamento, isso aqui alaga. A última chuva que deu aqui, eu levantei era umas três horas da madrugada. Porque eu sou assim: eu tô dormindo, mas eu me levanto pra ir ver como é que tá o nível da água. Essa água aqui ela nunca tinha lavado essa pista aí. Aí corri assim, entrou água bem aqui. Aí calcei uma bota cano longo e saí pela rua, saí por aí esperando a água descer. 
A possibilidade de alagamentos, ainda que remota, justifica o desconforto de moradores como Seu Laércio e Dona Júlia diante da intensidade de uma chuva que demora a terminar. $\mathrm{O}$ medo das enchentes marca a subjetividade dos mais velhos, repercutindo até em seu sono durante as noites chuvosas. A chuva também imprime marcas na paisagem da rua: as casas são construídas em um nível mais alto que o da pista e, em muitos casos, observa-se a construção de muretas de proteção contra a invasão da água. Essas práticas expressam a duração de relações com a água estabelecidas no processo de migração e ocupação do solo pelos moradores da Mena Barreto. Ao mesmo tempo, ainda que o transbordamento do Canal do Galo e os alagamentos não sejam tão constantes na Mena Barreto quanto em outros pontos da Bacia do Una, de um modo geral os canais da cidade hoje em dia estão transbordando com mais facilidade (Mansur et al. 2018).

Com o tempo, acabei incorporando o estado de alerta constante comum a pessoas como Dona Júlia e seu Laércio. Enquanto estive na Mena Barreto, o Canal do Galo não transbordou. Porém, a preocupação de que isso acontecesse me preencheu completamente. Se eu estivesse longe de casa enquanto chovia forte, não me tranquilizava até retornar à Mena Barreto. Quando estava em casa, a cada chuva eu me dirigia à margem do canal para olhar a movimentação das águas. Nessas ocasiões, o canal ganhava volume e correnteza, levando-me imaginar o rio que ali um dia havia existido.

A mudança na aparência do canal durante as grandes chuvas é capaz de transformar as atitudes de alguns moradores quanto a esses cursos d'água. Em uma das vezes que observava o canal prestes a transbordar, avistei algumas crianças e um rapaz a tomar banho no canal. Olhando para as águas do canal que passavam depressa, avistei de longe uma pessoa que vinha em minha direção carregada pela forte correnteza. Era um de meus conhecidos da rua, um jovem de, no máximo, 22 anos chamado Cleiton, que trabalhava fazendo pequenos bicos de limpeza e como auxiliar de construção. Quando saiu da água, ele contou que pulava de uma ponte no outro quarteirão, deixando-se levar pela água que aumentava de volume quando uma chuva como aquela caía. Perguntei se ele não passava mal tomando banho naquela água. Ele respondeu: "Eu aprendi a nadar nesse canal". E saiu andando, dizendo que iria tomar um banho com sabão grosso em sua casa. Três crianças brincavam na pista que margeia o canal. Quando o rapaz foi embora, uma delas se aproximou e disse: "Ele sempre toma banho no canal quando chove. A gente também tava tomando banho!" Repeti para as crianças a mesma pergunta que eu fizera ao jovem: "Essa água não faz mal pra vocês?” E um dos garotos me disse: "Não, mas se o senhor for tomar banho, vai passar mal". 


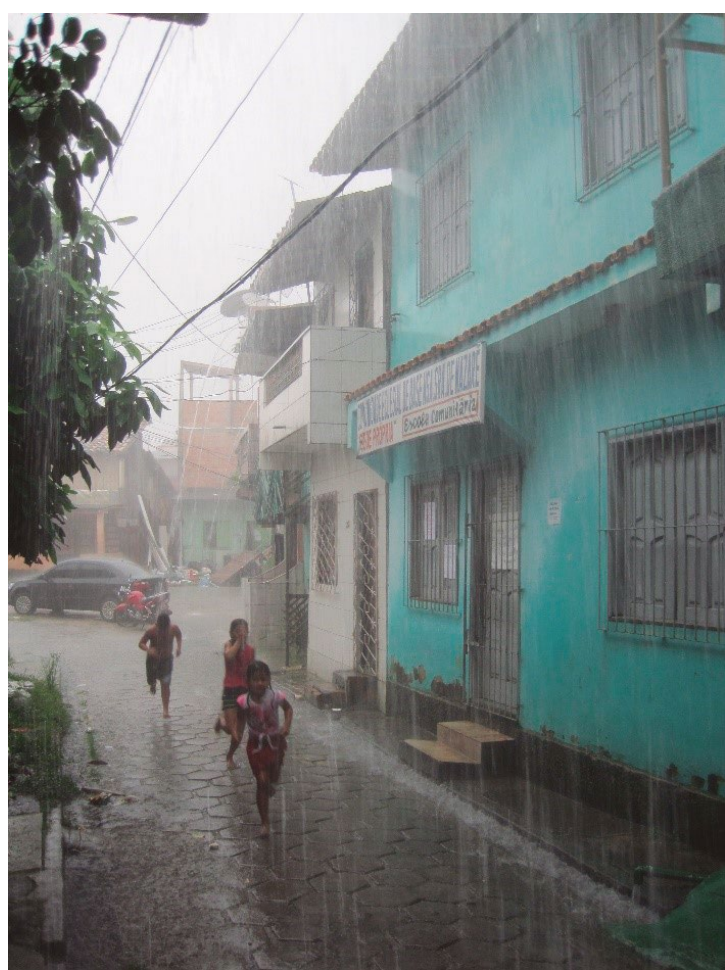

Figura 2 - Chuva na Mena Barreto.

Foto: Acervo pessoal do autor.

O banho no canal durante a chuva não é uma prática comum à maioria dos moradores da Mena Barreto ou de outras áreas próximas a canais em Belém, embora muitas vezes se perceba o banho nos canais como uma forma de sociabilidade juvenil. Ainda assim, em várias ocasiões, os moradores dessas áreas buscam retomar esta relação com o canal que um dia já foi rio ou igarapé. Durante a caminhada pelas margens do Canal do Galo até a Feira do Barreiro é possível observar bosques de árvores frutíferas plantados nos taludes dos canais. Naquele lugar, assim como em diversas áreas da Bacia do Una, as margens dos cursos d'água viram uma espécie de extensão do quintal ou jardim das residências. Alguns moradores usam esses locais para cultivar suas plantas, outros utilizam esses espaços para criar animais, como galinhas e porcos.

Casais namoram à beira dos canais e amigos se reúnem reproduzindo formas de sociabilidade ribeirinhas. Deques de madeira são erguidos sobre os taludes dos canais, criando salas de estar ou bares onde os moradores tomam sua cerveja. No bairro da Pedreira, próximo à avenida Pedro Miranda, os moradores da passagem 2 de junho construíram um terraço de concreto sobre o talude do Canal do Galo onde estão dispostos bancos e uma pia sob uma árvore que dá bastante sombra. Em um dos galhos uma placa está pendurada: "Orla da 2 de junho". O rio que foi negado pelas soluções técnicas de engenharia é evocado novamente nas práticas e eventos cotidianos daqueles que habitam próximo aos canais. O papel das margens dos canais é reconfigurado sob a lógica do magnetismo que as águas e a beira do rio exercem nas culturas ribeirinhas da Amazônia.

Não é raro alguns moradores referirem-se ao canal como "vala" ou "valão". Isso acontece em contextos que trazem à tona a questão da sujeira e do risco de contaminação pelo contato com a água. Também é nesses episódios que fica evidente como projetos de saneamento como o Projeto Una reproduzem as desigualdades sociais urbanas 
e a marginalização dos habitantes dos lugares onde houve intervenção. Um dos interlocutores da pesquisa, o senhor Laércio (na época com 73 anos), costumava entrar nas águas do Canal do Galo para retirar com as próprias mãos o lixo que obstruía o cano de concreto por onde escorrem as águas servidas das residências da Mena Barreto. Se Seu Laércio não retirasse o lixo que bloqueava a passagem da água, essas mesmas águas retornariam às casas pelos ralos, trazendo as impurezas dos canais.

Em uma das primeiras vezes em que visitei a sua residência, Seu Laércio havia se queixado de uma ferida no pé que demorava a cicatrizar devido à sua condição de diabético. Houve um dia em que ele não estava em casa e fui recebido por sua esposa Dona Lourdes. Ela me contou que o marido estava no hospital aguardando a liberação dos médicos para retornar à casa. Segundo Dona Lourdes, as repetidas vezes em que entrou no canal - somadas a outros fatores e, principalmente, à própria diabetes - pioraram o estado da ferida que ele tinha no pé, que infeccionou gravemente. Como consequência, ele tivera parte de uma perna amputada.

Ao entrar no canal para retirar lixo e assim liberar a vazão do esgoto, Seu Laércio assumia as responsabilidades da Prefeitura e do Governo do Estado, responsáveis pela drenagem urbana e pelo esgotamento sanitário, respectivamente. A necessidade de um morador da Mena Barreto entrar no Canal do Galo para fazer por conta própria a manutenção dos sistemas implementados pelo Projeto Una representa a consolidação incompleta do acesso à cidadania ambiental por meio da instalação de infraestrutura urbana e saneamento básico nesta área da Bacia do Una. A incompletude, neste caso, é percebida na ausência de uma política satisfatória a respeito de resíduos sólidos na cidade, a falta de manutenção do sistema de macrodrenagem e a ausência de rede adequada de esgotamento sanitário.

O pragmatismo de seu Laércio e outros moradores é uma resposta à percepção deles sobre os órgãos municipais e estaduais responsáveis pelo saneamento, os quais são vistos como ausentes, vagarosos e ineficientes, realizando trabalhos incompletos. Essas características percebidas no poder público levam os moradores a atuarem para resolver problemas de infraestrutura urbana por sua conta e risco, tal como haviam feito ao longo de todo o processo de migração, ocupação e conquista do solo urbano naquela parte da cidade. No passado, o trabalho coletivo espontâneo na forma de mutirões foi fundamental para construir casas, erguer pontes e aterrar ruas, transformando uma área alagadiça em local de moradia (Soares \& Hazeu 2019). 
Seu Laércio conviveu com as águas do igarapé - que depois se tornou canal - desde sua juventude, quando migrou da região do Marajó para Belém ajudado por uma irmã e constituiu família na Mena Barreto. Assim, entrar no canal representava a duração da prática cotidiana de cuidar de sua família e de sua casa, moradia erguida por ele mesmo sob as águas da Mena Barreto há mais de 40 anos.

\section{O banho na maré da Vila da Barca}

Exposta aos ventos ásperos

$E$ às enchentes lunares

Humilde "Vila da Barca", és burgo

flutuante,

Com becos estivados, luz mortiça e funérea,

Com moradores foragidos da cidade, Que em ti vão esconder a inconsciente miséria

De uma vida sem pão, nem sombras de esperança"

(Menezes 1953). ${ }^{7}$

É uma área mitológica de Belém. $\mathrm{Na}$ minha época de adolescente ainda se ia até lá para aspirar o ar da maresia, contemplar a baía escondida por muralhas construídas no litoral (mas ainda com baixa altura), ter contato com o povo e fazer pesquisa sobre as "raízes" da cultura popular. Bebia-se e cantava-se sobre as estivas, um olho nas companhias e outro varejando eventuais surpresas, inclusive - e sobretudo - as desagradáveis. Havia de vez em quando um incidente (ou mesmo acidente, quando alguém, mais ébrio, se desequilibrava nas pontes de madeira), mas nada grave. Esse tipo de excursão seria temerária, quando não suicida, nos nossos dias. (Pinto 2014) ${ }^{8}$.
A Vila da Barca é uma comunidade ribeirinha que se estende em estivas e palafitas sobre as águas da Baía do Guajará. O local é representado pelo senso comum como perigoso, frequentemente associado à pobreza e à violência, como fica evidente no final do segundo trecho disposto acima. Desde 2007, ela integra um projeto habitacional do Governo Federal que é parte do primeiro Programa de Aceleração do Crescimento (PAC) e que tem a Prefeitura de Belém como tomadora de recursos e executora de obras. Esse projeto remodelou parte da paisagem urbana da Vila da Barca. Uma parte dos moradores foi remanejada das casas palafitas onde moravam e reassentada em apartamentos construídos no mesmo local. Não obstante, essa intervenção do poder público, as obras foram interrompidas e grande parte da população da Vila da Barca continua vivendo em assentamentos precários (Rodrigues e Hantani 2019). Durante o trabalho de campo realizado em 2013 e 2014 tive a oportunidade conhecer o local. O motivo da ida à Vila da Barca foi o banho na maré do inverno amazônico.

Naquela semana, os jornais anunciaram as "águas grandes de março" que naquele ano - 2014 - vieram apenas no mês de abril. Como acontece sazonalmente, o nível da Baía do Guajará aumentou

7 Trecho do poema "Velha barca! Velha barca", de Bruno de Menezes.

8 Extraído do extinto Jornal Pessoal, do jornalista e sociólogo Lúcio Flavio Pinto. 
de tal maneira que as suas águas cobriram algumas ruas próximas do Mercado do Ver-o-Peso. Essas imagens da maré foram veiculadas pela imprensa todos os dias da semana. Quando soube por amigos sobre o "banho na maré" fiquei curioso para saber como e onde tomavam banho.

Manifestei minha vontade de conhecer o banho na maré e esperei até o dia seguinte quando fui convidado pelos vizinhos para ir até a Vila da Barca. Na sexta-feira, o banho bom daria às 13 horas. No horário combinado me dirigi até a esquina onde todos se encontravam para beber e jogar baralho. Éramos quatro pessoas. Fizemos uma coleta para comprar um litro de cachaça e seguimos a pé. Subimos a Rua Magno de Araújo, por dentro da Feira do Telégrafo, em direção à avenida Pedro Álvares Cabral e quando cruzamos esta avenida já estávamos na entrada da Vila da Barca.

Já era possível avistar os prédios construídos pelo projeto habitacional e o posto de saúde da Vila da Barca. Passamos pelos prédios de apartamento, cruzamos um campinho de futebol e a pracinha do conjunto habitacional. Logo apareceram os apartamentos que já estavam erguidos, mas que ainda não estavam prontos para serem entregues aos seus novos moradores. Depois desses prédios, vieram outros cujas obras pareciam longe de concluídas e aparentavam uma estagnação de bastante tempo, embora sua entrega estivesse prevista para o ano de 2014, conforme indicava uma placa em frente à obra. As edificações acabaram e seguimos por uma trilha lamacenta e rodeada de mato. À esquerda encontravam-se as casas palafitas remanescentes da Vila da Barca. No caminho, encontramos um cemitério de embarcações, algumas abandonadas, outras nas quais homens estavam trabalhando. Já enxergávamos a água barrenta do rio.

O que nos esperava à margem da baía não era o parapeito usado para se debruçar e admirar a paisagem fluvial, tampouco era o guarda-corpo usado para separar o canal da pista. Na orla da Vila da Barca, o acesso à água era livre, feito por uma escada de cimento que conduzia para dentro do rio e sobre a qual se debatiam as ondas da maré (Figura 3).

Não éramos apenas nós, da Mena Barreto, que estávamos no local. Todos aproveitavam as altas da maré, que do outro lado da cidade invadiam as lojas e do Ver-o-Peso, que deixavam preocupados os moradores das proximidades dos canais com a coincidência das chuvas com as marés. Naquela sexta-feira nublada chegavam grupos de adolescentes em algazarra dentro e fora d'água, enquanto os aviões sobrevoavam de rasante a Baía do Guajará prontos para aterrissar no aeroporto perto dali. Crianças curiosas se aproximavam atraídas pelo barulho, mulheres com suas crianças 
no colo e jovens se lançavam ao rio num clima de festa, recriando o verão em meio ao inverno amazônico chuvoso.

César, um dos amigos que estavam presentes me contava sobre suas aventuras na Baía do Guajará, uma vez em que a atravessou em uma canoa com dois amigos para pescar. Narrou ele que na ida, a água estava calma, a pescaria fora bemsucedida. Na volta, porém, uma chuva forte caiu e a baía se agitou. César e seus amigos se apressaram para chegar à margem. Já perto da terra firme, resolveram pegar um atalho pelo meio de duas grandes balsas de ferro. De repente, perceberam que o vento e as águas revoltas estavam fazendo com que as balsas se aproximassem. No meio, a canoinha de madeira seria esmagada por aqueles dois imensos paredões de metal. Apressaram-se nos remos enquanto o caminho se estreitava cada vez mais. Remando cada vez mais rápido para se salvar, perderam os peixes que tinham apanhado, perderam as varas de pescar, perderam a cachaça, mas conseguiram finalmente chegar à margem. Depois desse dia César disse que nunca mais quis atravessar a baía.

Ele também falou sobre os antigos espaços de sociabilidade na orla de Belém onde ele, sua família e seus amigos se reuniam antigamente. Contou sobre os churrascos que faziam em um lugar chamado "Porto Louco", um conjunto de balsas e embarcações abandonadas ao lado da Vila da Barca. Segundo César: "enchia de gente, era mulher, era criança, a gente levava carne, levava uma churrasqueira, fazia um churrasco em cima da balsa". "Aí a maré ia enchendo, enchia até a balsa ficar debaixo d'água." Ele prosseguiu dizendo: "Quando tiraram aquela balsa de lá, a gente pegou muito camarão ali, cada camarãozão, olha!", e indicava com as mãos o tamanho dos camarões. "A gente pegou muito peixe, tudo aquilo se criava embaixo da balsa, até cobra tinha ali!". Régis, um dos amigos que estava conosco, contou que naquele local havia pescado um filhote ${ }^{9}$ de 2 quilos. "Peixe de pescaria é pra botar pra correr, né?”, disse ele, indicando que o produto da pesca deveria ser de consumo coletivo dos moradores. César, por sua vez, contou que já havia pescado uma arraia imensa que lhe serviu de alimento.

Entramos na água. A escada que levava à baía acabara num plano de cimento onde eu anda podia dar pé. Mais à frente, porém, já estava fundo. Muito longe, havia uma boia de sinalização onde algumas crianças se seguravam. Após entrarem na água, meus vizinhos passavam um sabão grosso no corpo, inclusive nos cabelos. Repeti essa operação pensando que faziam isso para se proteger das impurezas daquela água,

9 Também conhecido com piraíba (Brachyplatystoma filamentosum) o filhote é um peixe "nobre" das águas amazônicas. 
pois o fato de tomarem banho ali não significava que considerassem a água limpa. Bem ao nosso lado havia um cano de concreto que ficava quase submerso pela maré. Perguntei se aquele cano estava funcionando e me disseram que não, mas que passaria a funcionar após a conclusão nas obras da Vila da Barca, quando os esgotos das novas unidades habitacionais seriam despejados na Baía do Guajará por aquele mesmo cano.
A água estava barrenta, refrescante e agitada. $\mathrm{O}$ volume da água e sua dinâmica revoltosa evocavam vida, transformava sua aparência, faziam crer que aquelas águas que recebem o esgoto de uma cidade com mais de um milhão e quatrocentos habitantes eram limpas, próprias para o banho e o lazer. Não havia sinal de dejetos, sujeira ou mal cheiro. Era como se a grande maré chegasse para purificar as águas sujas do entorno de Belém.

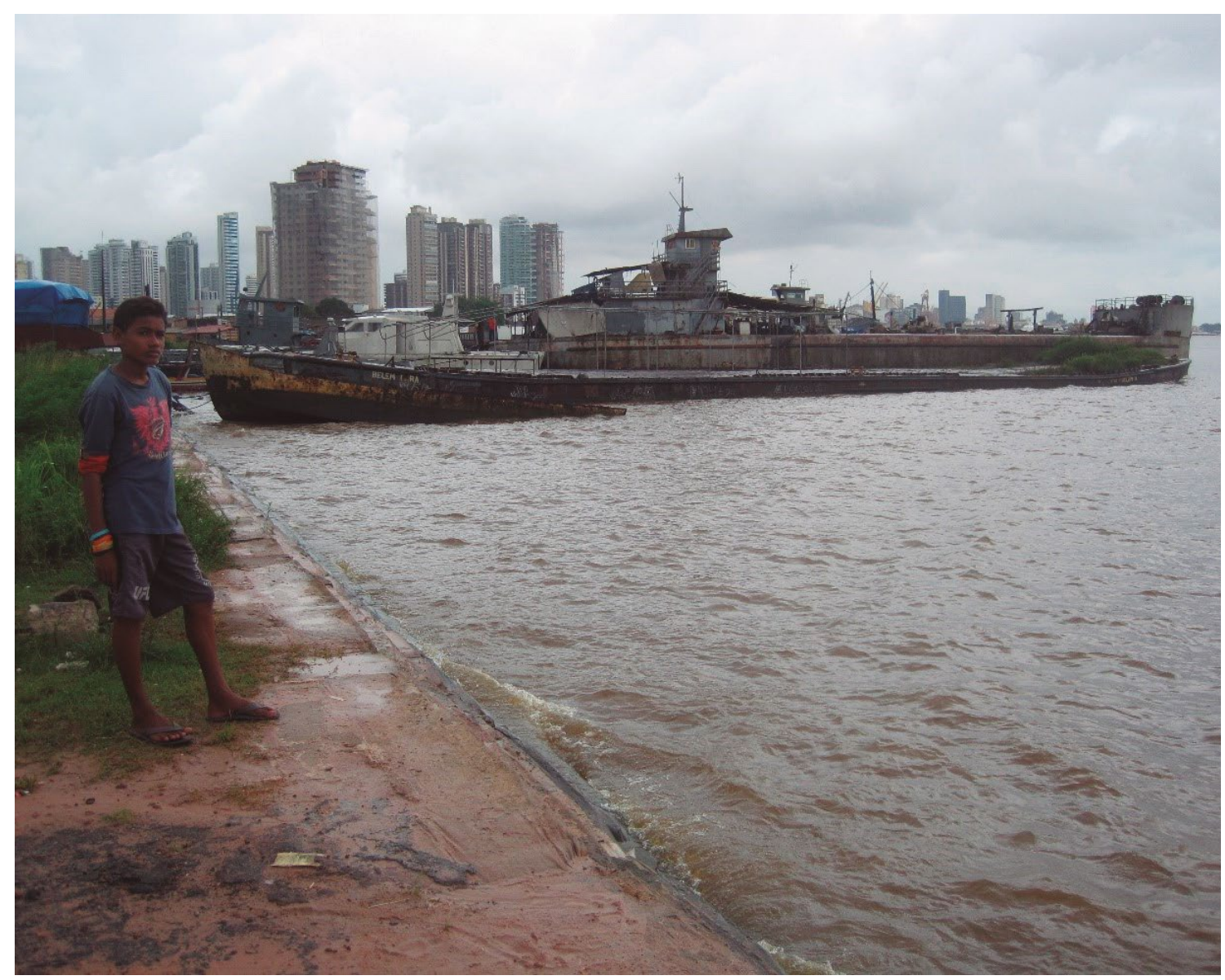

Figura 3 - Orla da Vila da Barca. Foto: Acervo pessoal do autor. 
“A maré quebrou”, disse César. Já estava começando a secar. "Quando fica mais seco a água começa a cheirar mal”, disse ele. A cachaça também já havia terminado. Chegou a hora de voltarmos. Para retornarmos seguimos um caminho diferente. Passamos pelo outro lado do projeto habitacional, onde pude ver a entrada para as palafitas da Vila da Barca em plena Avenida Pedro Álvares Cabral, avenida onde são erguidos luxuosos arranha-céus com vistas para a Baía do Guajará.

O Canal do Galo conduz ao Canal do Una, que lança suas águas na Baía do Guajará. Os moradores da Mena Barreto mimetizam o caminho do curso d'água se dirigindo à margem da baía. O sistema hidrográfico da Bacia do Una se sobrepõe aos sistemas sociais que traçam redes de relações que se vetorizam dos canais para a baía e vice- versa. Os moradores da Mena Barreto se consultam e são atendidos no Posto de Saúde da Vila da Barca. Possuem parentes e amigos no local, estabelecem relações de trabalho e comércio, além do banho, é claro. Assim, buscam a relação ancestral com a água se aproximando do canais de macrodrenagem, mas também caminhando até as margens da Vila da Barca onde ainda existem não apenas "janelas" para o rio, mas também caminhos e escadas que levam ao refrigério nas águas turvas e mornas do estuário guajarino.

\section{A CIDADE E SUAS MARGENS}

Enquanto tomávamos banho na Baía do Guajará era possível observar a intensa verticalização que a orla fluvial central vem sofrendo. Por mais que estivéssemos em uma vila ribeirinha localizada praticamente no centro da cidade, quando atravessássemos a Avenida Pedro Álvares Cabral nos depararíamos com vários arranha-céus luxuosos - alguns ainda em construção - cujo principal diferencial no mercado imobiliário seria justamente a vista para o rio. Esses prédios aparecem como monumentos de uma nova Belém vertical que agora volta seus olhares e seus investimentos econômicos de grande porte para o rio.

A contraditória relação da cidade com o rio, que passa pela sua negação e, recentemente, pela revalorização do ambiente fluvial na vida urbana, é colocada nos seguintes termos por Bolle (2008), alemão radicado no Brasil, escritor e estudioso da literatura paraense:

\footnotetext{
Dando as costas para o rio e olhando para o Leste, enxergamos apenas uma muralha de prédios. Ora, é justamente essa muralha que constitui, neste caso, um outro ícone urbano expressivo: a cidade vivendo de costas para o rio. As beiras do rio e do estuário eram associadas às águas turmas e à lama, à massa de gente popular, ao barulho de barcos e vendedores, ao trabalho braçal e ao suor, aos detritos e aos dejetos. Esse padrão da classe média de viver de costas para o rio prolongou-se da Belle Époque até os anos 1980 adentro, só começando a mudar a partir da década de 90. (Bolle 2008: 106).
} 
A transformação deste padrão a partir dos anos 90 do século XX está relacionada à perda da importância econômica do porto central de Belém. Com o declínio da zona portuária, surge a necessidade de se pensar em novos investimentos para a área, o que resulta em iniciativas ligadas ora ao turismo de massa, ora ao mercado imobiliário, como mostram os trabalhos de Ponte (2005; 2006) sobre as intervenções urbanísticas na orla fluvial central de Belém. É interessante ressaltar, ainda conforme as reflexõesdo autor, que este movimento de revalorização da orla belemense vem acompanhado de discursos presentes na mídia e no debate político sobre o que se chamou de "devolução" do acesso ao rio e à baía para os habitantes da cidade.

A ideia recorrentemente aceita de a cidade ter se estruturado "de costas para o rio" e os discursos da retomada e "devolução" da orla em muito contrastam com as práticas de moradores da Vila da Barca e de outros sujeitos que se locomovem de seus bairros e comunidades para banhar-se na maré das águas que contornam a cidade. Tal é o caso de meus amigos da Mena Barreto, os quais se deslocam das margens do Canal do Galo para as margens da baía a fim de vivenciar o contato com a água. Logo, diferentes formas de relacionar-se com o rio foram construídas ao longo do tempo e de acordo com os valores e visões de mundo dos sujeitos envolvidos no uso e desuso de espaços urbanos como as margens fluviais da cidade.

O padre missionário e viajante Daniel P. Kidder, que esteve em Belém entre 1840 e 1842 relatou em seus escritos o remoto hábito das classes populares de tomar banho na Baía do Guajará:

Vários objetos e costumes observam-se
no Pará, que parecem ser totalmente
peculiares ao lugar. Em certo ponto
da cidade, onde se abatem as reses
destinadas ao consumo, vêem-se
inúmeros corvos pousados sôbre
as árvores ou descrevendo lentas
evoluções no ar. Ao longo da margem
do rio notam-se numerosas pessoas
banhando-se, tanto pela manhã como á
tarde. Não há cerimônia nessas abluções
tão agradáveis quão necessárias. É
comum verem-se homens, mulheres
e crianças das classes mais humildes,
nadando, mergulhando em direções
diferentes, todos ao mesmo tempo
(Kidder 2002: 171).

O relato de Kidder chama atenção para a duração no tempo desta prática na orla belemense. Nota-se, pela descrição do autor, que no século XIX esse banho se dava nas imediações do Antigo Curro Municipal, hoje conhecido como "Curro Velho", o qual se encontra muito próximo ao que hoje em dia é Vila da Barca. A partir da década de 1990, o poder público começa a investir na "retomada" da orla fluvial de Belém para criar espaços de consumo, sociabilidade, lazer e sítios turísticos que tornassem a cidade atrativa a consumidores e investimentos econômicos. Enquanto isso, as classes populares têm mantido uma relação ancestral com o rio que 
escapou ao discurso oficial tacitamente aceito e difundido segundo o qual, até a década de 1990, Belém estava "de costas para o rio". Esse também é o caso da história contada por César sobre o local que chamava de "Porto Louco".

O espaço de sociabilidade de César e sua família às margens da baía foi fechado para a construção de um prédio residencial. É de conhecimento público que a construção do prédio esteve embargada pela justiça e suas obras foram interrompidas durante certo tempo. Eventualmente, as obras do edifício foram concluídas, mas não antes da história percorrer os jornais de circulação regional pelo prédio ter sua construção baseada em fraudes ${ }^{10}: 0$ edifício foi construído em cima de uma área de aterro, o que não é recomendado do ponto de vista técnico e nem permitido pela legislação do município, além de constituir crime ambiental por estar localizado em uma APP (Área de Proteção Permanente) de acordo com o Novo Código Florestal Brasileiro (Pinto 2014).

Essas dinâmicas de utilização das margens da Baía do Guajará levam à reflexão sobre a múltipla vocação do que se entende contemporaneamente por "orla" na cidade de Belém, alvo de interesses e significações contrastantes quando considerados os atores em conflito nesses territórios. Por um lado, esses conflitos refletem a diversidade cultural da metrópole amazônica e as particularidades do processo histórico de consolidação da cidade que, desde a sua fundação no século XVII, oscilou em uma dialética de utilização/negação/retomada de sua relação com a água. Por outro, há de se considerar as iniciativas do poder público geralmente voltadas para as camadas altas e médias com seus desejos de "recuperar" e "reconquistar" a orla da cidade e que se manifesta na criação de espaços voltados para a fruição da paisagem fluvial. Tal é o caso do Ver-o-Rio, da Estação das Docas, do Projeto Feliz Luzitânia e, mais recentemente, do Portal da Amazônia (Ponte 2006).

Em comum com os projetos de macrodrenagem das águas que recortam a cidade, as intervenções na orla também constituem formas de disciplinamento do uso desses lugares e dos corpos e subjetividades que ali estão presentes. Além disso, nenhuma dessas iniciativas dialoga de fato com a ideia - no passado e no presente - de uma Belém fluvial, integrando o ambiente hídrico à malha urbana ${ }^{11}$ ou promovendo o tipo de relação com o rio que é observada no banho das marés e na permanência

10 Jornal Pessoal 2014:7.

11 O Projeto de Macrodrenagem da Bacia do Tucunduba foi concebido a partir do paradigma dos rios urbanos incentivado pela ONU e pode ser considerado, com ressalvas, uma exceção no universo das políticas públicas ligadas à gestão das águas urbanas em Belém (Barbosa et al. 2003). 
de pequenas embarcações abaixo das palafitas da Vila da Barca.

As problemáticas referentes à incorporação da Bacia do Una à paisagem urbana belemense tangenciam algumas questões relativas à "devolução" ou "revitalização" da orla fluvial central no que diz respeito ao acesso à água não só como recurso, mas sobretudo como meio e local onde se vive. Tanto na orla como no interior da cidade existem guarda-corpos, muros, parapeitos e passarelas que isolam as pessoas da água, ao invés de conduzir a ela. Uma exceção pode ser a subutilizada rampa para esportes náuticos no Projeto Ver-o-Rio, há algumas quadras da Mena Barreto e da Vila da Barca. De um modo geral, entretanto, o que é pensado nesses projetos de intervenção urbanística é o uso do solo urbano, sendo a terra o elemento referencial, em detrimento da água e das relações efetivas com esse outro elemento.

$\mathrm{O}$ usos dados às margens da orla e dos canais remetem a dinâmicas sociais de proximidade com o rio que são recriadas pelos sujeitos no cotidiano por meio de suas formas de sociabilidade e de sua memória, ressoando nas práticas de contato com a água estabelecidas em Belém ao longo do tempo. Por isso, o banho na maré da Baía do Guajará, assim como o banho nos canais e a apropriação de suas margens como espaços de sociabilidade, plantio de árvores, criação de animais e como extensão do espaço doméstico não precisam ser classificados neste trabalho como usos inadequados dos espaços e equipamentos ali existentes. Quando enquadrados fora das normatividades propostas pelas políticas públicas implementadas nesses lugares, essas práticas revelam maneiras de ressignificar a paisagem hídrica e reconquistar a cidade de acordo com as necessidades e visões de mundo dos moradores dessas áreas, processo que é informado pela memória. A compreensão dessas práticas contribui para que a cidade e o resultado das políticas urbanas sejam considerados menos como a expressão do fracasso ou triunfo da racionalidade cartesiana e mais como reflexo da experiência compartilhada a partir das trajetórias e itinerários de seus habitantes.

A observação das atitudes cotidianas relacionadas à água em Belém também permite notar a superposição de camadas temporais existentes em um mesmo espaço. Os cursos d'água transpostos para os canais, os igarapés aterrados, os charcos pobres de antigamente e mesmo partes da antiga orla fluvial encontram-se sobrepostos pela memória nas paisagens urbanas de Belém a lugares onde hoje em dia existem edifícios de alto poder aquisitivo, intensa especulação imobiliária e tráfego de automóveis. Os antigos igapós e igarapés, assim como as práticas a eles 
associadas, hoje são vivenciados na ordem dos espaços fantásticos (Eckert \& Rocha 2005), isto é, espaços que não existem mais da maneira como eram antigamente, mas são trazidos à tona pelas narrativas e práticas de seus habitantes que acompanharam as modificações da cidade e de sua relação com suas paisagens fluviais ao longo do tempo (Figura 4).

\section{CONSIDERAÇÕES FINAIS}

A cidade de Belém e a Bacia do Una passaram durante o século XX e início do século XXI por intervenções urbanísticas que alteraram substancialmente a paisagem urbana e os modos de vida de seus habitantes, sobretudo no que diz respeito à relação com a água. Projetos como a macrodrenagem da Bacia do Una, por exemplo,

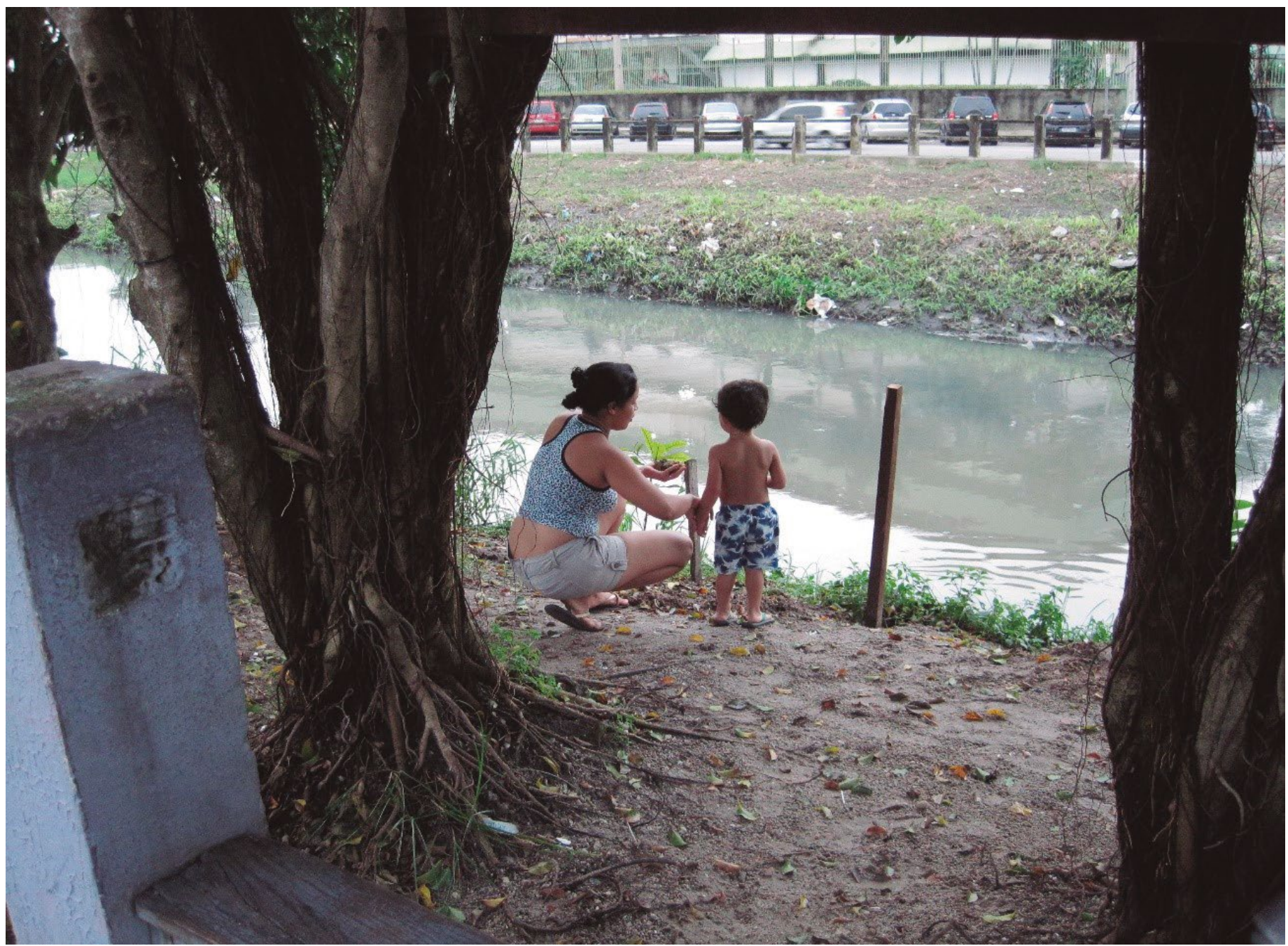

Figura 4 - Margens. Foto: Acervo pessoal do autor. 
foram responsáveis por institucionalizar as fronteiras entre cidade e natureza, o que também significa dirigir as condutas e práticas dos habitantes das áreas beneficiadas em relação às águas urbanas e aos equipamentos que foram instalados. Além disso, tais projetos resultaram na reprodução das desigualdades urbanas e na marginalização dos habitantes das áreas beneficiadas, na medida em que responderam parcialmente aos seus objetivos e às necessidades dos moradores.

Esse contexto da cidade e das políticas urbanas relacionadas à água desencadearam dois processos fundamentalmente ligados à memória. Em primeiro lugar, Bachelard (1988) recorda que o esforço da duração é um esforço para assegurar a continuidade do ser expresso nas coisas do mundo. No caso deste trabalho, o esforço de fazer durar contra a finitude do ser é percebido nas tentativas dos sujeitos de recuperar, reavivar e de continuar evocando as imagens do rio e do igarapé, ainda que em uma conjuntura de crise urbana e ambiental. Em segundo, as práticas dos habitantes do entorno dos canais e da orla fluvial representam resistências ao modus operandi das políticas públicas baseadas na supressão da água e que foram pensadas e implementadas de modo vertical nesses espaços. Assim, o canal se torna rio e igarapé novamente, o banho na baía poluída torna-se de novo possível, ao mesmo tempo em que essas transformações são revertidas. As políticas criaram fronteiras entre cidade e água, mas o movimento das marés e as formas de sociabilidade tornam essas fronteiras ambíguas, móveis e situacionais.

A experiência na Bacia do Una mostrou como a memória vibra no tempo da cidade, estando sujeita aos desígnios dos sujeitos, às descontinuidades de suas experiências, às mudanças em suas trajetórias e aos rearranjos da vida urbana. O trabalho também apontou como a água tem papel fundamental no tensionamento da memória. Mais do que elemento natural inerte ou um recurso, a água agencia relações sociais na cidade, motivando projetos milionários de intervenção urbana, recusando a própria supressão, invadindo casas e corroendo paredes. Ao mesmo tempo, a água também integra o cotidiano e a sociabilidade de populações que viveram sobre a água e a ela retornam, reinserindo o tempo da cidade no tempo das marés. 


\section{REFERÊNCIAS}

Abelém, Auriléia Gomes. 1988. Urbanização e remoção: por que e pra quem? Belém: UFPA.

Almeida, C. M. R. 2011. Belém do Pará, uma cidade entre as águas: História, natureza e definição territorial em princípios do século XIX. In Simpósio Nacional de História 26. São Paulo, SP: Universidade de São Paulo. http://www.snh2011.anpuh.org/site/anaiscomplementares\#C

Bachelard, Gaston. 2013. A água e os sonhos: Ensaio sobre a imaginação da matéria. São Paulo: Martins Fontes.

Bachelard, Gaston. 1988. A dialética da duração. São Paulo: Ática.

Baena, Antonio Ladislau M. 1839. Ensaio Corográfico sobre a Província do Pará. Belém: Typ. de Santos \& Menor.

Barbosa, Maria José et al. 2003. Estudo de caso: urbanização do igarapé Tucunduba, gestão de rios urbanos. Belém: UFPA.

Bateson, Gregory. 1987. Form, substance and diference, in Steps to an ecology of mind, pp. 448-464. Londres: Jason Aronson Inc.

Bolle, Willie. 2008. Belém, porta de entrada na Amazônia, in Cidades na floresta, pp.99-150. Belém: Annablume.

Cardoso, Ana Cláudia D.; Ventura Neto, Raul Silva. 2013. A evolução urbana de Belém: trajetória de ambiguidades e conflitos socioambientais. Cadernos Metrópole. 15(29): 55-75.

Chevalier, Denis. 1991. Des savoirs efficaces. Terrain.16: 5-11.

Das, Veena e Poole, Deborah. 2004. State and its margins, in Anthropology in the margins of the state, pp.6-32. Santa Fe: School of American Research Press.

Devos, Rafael Victorino; Soares, Ana Paula Marcante e Rocha, Ana Luiza Carvalho. 2010. Habitantes do Arroio: memória ambiental das águas urbanas. Desenvolvimento e Meio Ambiente. 22: 51-64.

Eckert, Cornelia. 2010. Cidade e Política: nas trilhas de uma Antropologia da e na cidade no Brasil, in Horizontes das Ciências Sociais no Brasil, pp.155-196. São Paulo: ANPOCS.

Eckert, Cornelia e Rocha, Ana Luiza. 2005. O tempo e a cidade. Porto Alegre: UFRGS. 
Foucault, Michel. 2002. Aula de 17 de março de 1976, in Em defesa da sociedade, Curso no Collége de France, pp. 285-315. São Paulo: Martins Fontes.

Geertz, Clifford. 1991. O dilema do antropólogo: entre "estar lá" e "estar aqui". Cadernos de Campo. 7(7): 205-35.

Kidder, Daniel. 2002. Reminiscências de Viagens e Permanências nas Províncias do Norte do Brasil. Belo Horizonte: Itatiaia.

Lefebvre, Henri. 2004. A revolução urbana. Belo Horizonte.

Mansur, Andressa Viana et al. 2018. Adapting to urban challenges in the Amazon: flood risk and infrastructure deficiencies in Belém, Brazil. Regional Environmental Change, 18 (5): 1411-1426.

Moreira, Eidorfe. 1989. Obras reunidas de Eidorfe Moreira. Vol. VII. Belém: Cejup.

Meira Filho, Augusto. 1973. Contribuição à História de Belém. Belém: Imprensa Oficial do Estado.

Menezes, Bruno de. 1953. Lua sonâmbula. Belém: Falangola.

Kaika, Maria 2005. City of flows: Water, modernity, and the city. New York: Routledge.

Pará. 2006. Informações gerais sobre o Projeto Una. Belém.

Penteado, Antônio Rocha. 1968. Belém: Estudo de Geografia Urbana. v. 1. Belém: UFPA.

Pereira, J. A. R. 2003. Saneamento Ambiental em áreas urbanas: esgotamento sanitário na região metropolitana de Belém. Belém: UFPA.

Pinto, Lúcio Flávio. 2014. Jornal Pessoal 559, $2^{\text {a }}$ quinzena de abril de 2014. p.8.

Sant'anna. Denise Bernuzzi. 2007. Cidade das águas: usos de rios, córregos, bicas e chafarizes em São Paulo (1822-1901). São Paulo: SENAC.

Ponte, Juliano Ximenes. 2006. Sustentabilidade, desenvolvimento e planejamento urbano: reconfiguração das margens fluviais de Belém. Revista Brasileira de Estudos Urbanos e Regionais. 8 (1): 27-44.

Rodrigues, Roberta Menezes e Hantani, Daniele Saori E. 2019. Moradia e urbanização das baixadas de Belém: uma análise do PAC urbanização de assentamentos precários. In XVIII Enampur. Natal, RN: Anpur. http://anpur.org.br/xviiienanpur/anais

Silva, A. M. 2003. Gestão de conflitos pelo uso da água em bacias hidrográficas urbanas. Dissertação de mestrado, Programa de Pós-Graduação em Engenharia Civil, Universidade Federal do Pará. 
Soares, Pedro Paulo M.A. 2016. Memória ambiental na Bacia do Una: Estudo antropológico sobre transformações urbanas e políticas públicas de saneamento em Belém (PA). Tese de Doutorado, Programa de Pós-Graduação em Antropologia Social, Universidade Federal do Rio Grande do Sul.

Soares, Pedro Paulo M.A.; Cruz, Sandra Helena Ribeiro. 2019. A Ecologia Política das inundações urbanas na Bacia do Una em Belém (PA). Emancipação. 19:1-15.

Soares, Pedro Paulo M. A.; Hazeu, Marcel Theodoor. 2019. Trabalho, migração e contrastes socioespaciais urbanos: trajetórias sociais de habitantes da Bacia do Una em Belém (PA). Ponto Urbe 24.

Soares, Pedro Paulo M. A.; Cruz, Sandra Helena Ribeiro e Costa, José Alexandre de Jesus. 2020. Inundações urbanas e violações dos direitos humanos na bacia do Una em Belém do Pará, in Gestão da água: desafios sociopolíticos e sociotécnicos na Amazônia e no Nordeste brasileiros, pp.100-122. Belém: NUMA/UFPA.

Valle, A. S. e Oliveira, José Aldemir. 2003. A cidade de Manaus: análise da produção do espaço urbano a partir dos igarapés, in Cidade de Manaus: visões interdisciplinares, pp.151-184. Manaus: EDUA.

Trindade Júnior, Saint-Clair. 1997. Produção do espaço e uso do solo em Belém. Belém: NAEA/UFPA. Velho, Gilberto. 1994. Observando o familiar, in Individualismo e cultura: notas para uma Antropologia da sociedade contemporânea, pp. 123-132. Rio de Janeiro: Jorge Zahar. 
